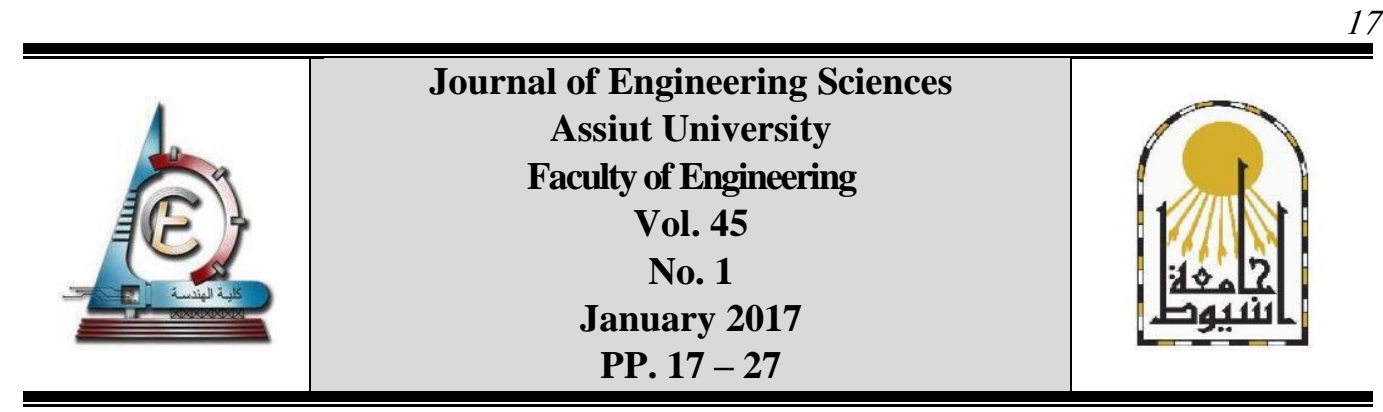

\title{
CONTRACTION EFFECT UPSTREAM ABUTMENTS ON VELOCITY AND SCOUR: EXPERIMENTALAND THEORETICAL STUDY USING IRIC SOFTWARE
}

\author{
Maha R. Fahmy ${ }^{1}$ * and Mohamed A. Nassar ${ }^{2}$ \\ ${ }^{1}$ Water Eng. and Water Structures Depart., Faculty of Engineering, Zagazig University, Egypt, \\ ${ }^{2}$ Department of Construction Engineering, College of Engineering in Al-Qunfudhah, Umm Al- \\ Qura University, KSA, On leave from Water Engineering and Water Structures Department, \\ Faculty of Engineering, Zagazig University, Egypt.
}

Received 15 September 2016; Accepted 20 October 2016

\begin{abstract}
This paper studies scour features and velocity field using experimental and numerical models at rectangular piers under influence of contraction upstream abutments. A bridge model of two vents of $8 \mathrm{~cm}$ width each is built to conduct experiments. Extra-piles are proposed upstream rectangular abutments. Different relative extensions of piles are tested. In addition, a new abutment of a relative width ranges within 0.0 to 1.25 was proposed instead of piles. The flume's dimensions are $40 \mathrm{~cm}$ width, $20 \mathrm{~cm}$ deepness and $400 \mathrm{~cm}$ length. Some design rules are deduced to reduce scour upstream rectangular piers. Cases of locating piles upstream abutments are simulated numerically using SToRM solver in iRIC software. The numerical results indicate that, piles of a relative extension to vent width $=4.812$ produce the minimal flow velocity near rectangular piers.
\end{abstract}

Keywords: experiments, numerical, simulations, scour, iRIC and SToRM solver.

\section{Introduction}

Scour may endanger the protection of hydraulic structures. Deng and Cai (2010) indicated that, scouring activities are the major reason for about $60 \%$ of bridge collapse in US. Mohammed et al., (2007) indicated that scouring can be reduced by $15 \%$ using the profile of streamlined pier. Oben-Nyarko and Ettema (2011) indicated that locating the pier near to abutment amplified scouring at abutments by $<10 \%$.Asimplified scour equation was given by Chitale (1962), see Sheppard (2011). It was built on actual measuring for scour in some channels in India.

$$
\mathrm{s}_{\mathrm{c}} / \mathrm{y}_{\mathrm{u}}=6.65 \mathrm{~F}_{\mathrm{u}}-0.51-5.49 \mathrm{~F}_{\mathrm{u}}^{2}
$$

\footnotetext{
* Corresponding author

Email address: maha.rashad55@yahoo.com
} 
In which: $\mathrm{s}_{\mathrm{c}}$ : the deepness of scour, $\mathrm{y}_{\mathrm{u}}$ : thedeepness of flow just upstream piers, $\mathrm{F}_{\mathrm{u}}$ : upstream Froude value, $\mathrm{F}_{\mathrm{u}}=\mathrm{v}_{\mathrm{u}} / \sqrt{\mathrm{gy}_{\mathrm{u}}}$

The modification of existing bridges may affect scour at rectangular piers. Mowafy and Fahmy (2001) inspected the constructing effect of a new bridge near an existing one on scour and flow conditions. The optimum space between two rectangular piers was proposed to be zero to minimize scour at downstream pier. Mowafy and EI-Sayed (2000) inspected the influence of weeds gathering on scour process. Negm et al. (2009) proposed a deflector to control scouring. The total scour decreased by $68 \%$. Many researchers inspected scour close to abutments at presence of some plates like collares as Gogus and Dogan (2010), and Li et al. (2006).

Radice and Davari (2014) suggested roughening elements as a device to control scour at abutments. Mojtaba et al. (2012) inspected scouring at three types of abutments. The deepness reduction of hole is $19-31.2 \%$ and $6-26 \%$ of buried wing and the wing walls, respectively in the comparison with vertical wall.

The numerical simulation is a simple way to obtain fast and accurate results. Many numerical simulations in open channels were published to simulate the velocity and sediment transport in Nile River and its branches as Elfiky, et al. (2002, 2004 and 2010), Negm, et al. (2010) and Nassar (2011). In addition, the implementation of numerical simulation to detect scour or velocity values near bridge supports were applied as Esmaeili, et al., (2009), Mohamed, et al.,(2015).

In this study, scour and velocity upstream rectangular piers are inspected experimentally and numerically under influence of contraction upstream abutments. The research focuses on the extensions of the contraction. Controlling parameters are given. The major results are discussed in details. In addition, results of statistical analysis and numerical simulations using SToRM solver are detailed.

\section{Controlling parameters}

The controlling parameters of scour at rectangular piers can be derived based on the dimensional analysis, Melville (2008). The following dimensionless parameters presented in equation (2) are obtained:

$\mathrm{s}_{\mathrm{cr}}=$ function of $\left(y_{r}, \mathrm{~F}_{\mathrm{down}}, \mathrm{V}_{\mathrm{r}}, \mathrm{w}_{\mathrm{r}}, \mathrm{L}_{\mathrm{r}}\right)$

In which:

$\mathrm{s}_{\mathrm{cr}}=\left(\mathrm{s}_{\mathrm{c}} / \mathrm{y}_{\mathrm{t}}\right):$ the related deepness of scour,

$y_{r}=\mathrm{y}_{\mathrm{u}} / \mathrm{y}_{\mathrm{t}}:$ the related upstream water depth,

$\mathrm{y}_{\mathrm{t}}$ : the deepness of flow downstream the bridge,

$\mathrm{F}_{\text {down }}$ : Froude value downstream the bridge, $\mathrm{F}_{\text {down }}=\mathrm{V}_{\mathrm{t}} / \sqrt{\mathrm{gy}_{\mathrm{t}}}$,

$\mathrm{V}_{\mathrm{r}}=\mathrm{V}_{\mathrm{c}} / \mathrm{V}_{\mathrm{t}}$ : the related critical flow velocity of soil,

$\mathrm{V}_{\mathrm{c}}$ : the critical flow velocity for the soil,

$\mathrm{V}_{\mathrm{t}}$ : the average velocity downstream the bridge,

$\mathrm{w}_{\mathrm{r}}=\mathrm{w}_{\mathrm{p}} / \mathrm{b}:$ the new abutment's related breadth, 
$\mathrm{w}_{\mathrm{p}}$ : the new abutment's breadth,

$\mathrm{L}_{\mathrm{r}}=\mathrm{L}_{\mathrm{p}} / \mathrm{b}$ : the related extension of piles to abutments' breadth, and

$\mathrm{L}_{\mathrm{p}}$ : the extension of new piles.

Figures (1and 2) give the major variables appeared in the study.

\section{Lab works}

The experiments are collected in the hydraulics laboratory at Engineering Faculty, Zagazig University using a flume of $40 \times 20 \times 400 \mathrm{~cm}$ for width, deepness and length, respectively. Figure (2A) presents the flume details. A calibrated orifice-meter is utilized to measure discharges. The flow depths are measured using point gauges. Figure (2B) shows an image for the bridge model with extra-piles upstream abutment. The location and extension of constructed new piles can be seen from the figure.
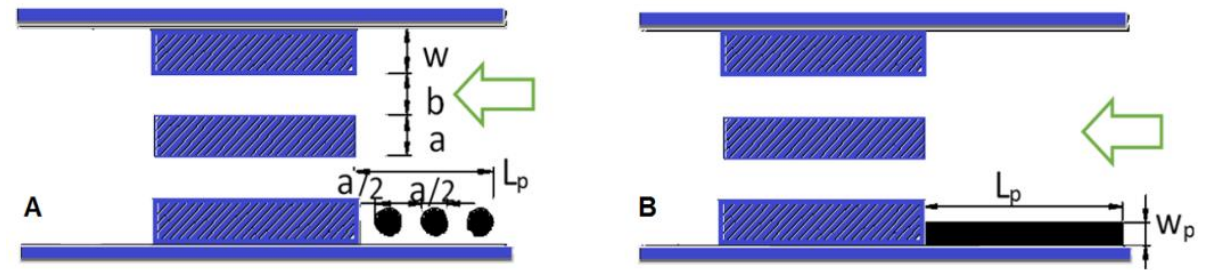

Fig. 1. Model details $[\mathrm{A}]$ the extra piles case $[\mathrm{B}]$ the extra abutment case

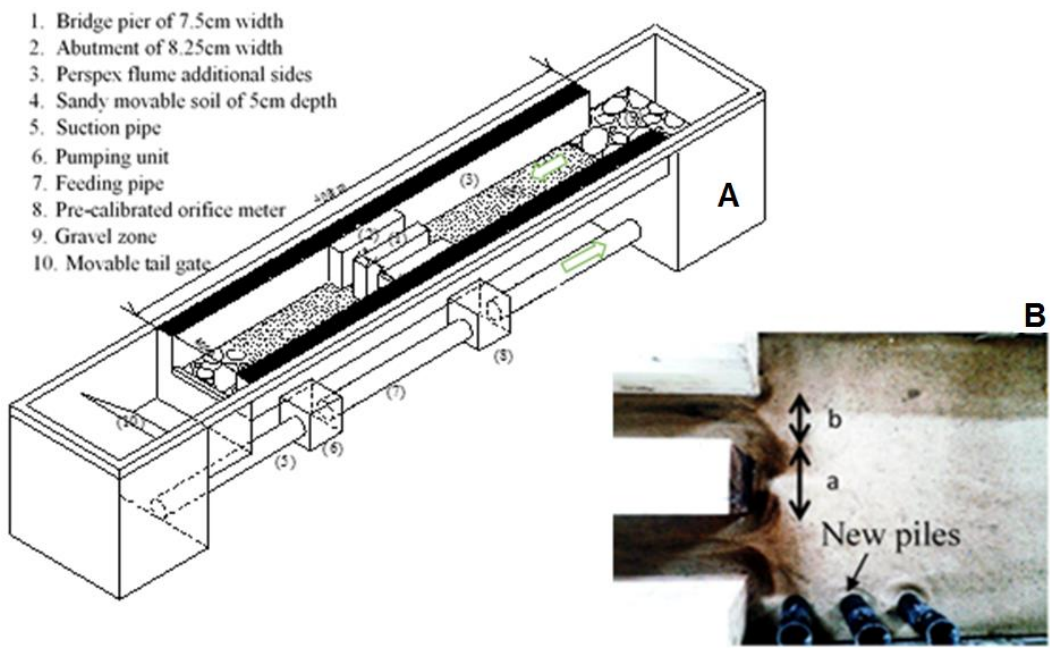

Fig. 2. $[\mathrm{A}]$ the flume details $[\mathrm{B}] \mathrm{an}$ image of the extra-piles case

The bridge model consists of two square nose abutments and pier (see figure 1A). The pier width and length are $7.5 \mathrm{~cm}$ and $40 \mathrm{~cm}$ respectively. The abutment width and length are $8.25 \mathrm{~cm}$ and $40 \mathrm{~cm}$ respectively. The two vents width is $8 \mathrm{~cm}$ (see figure $2 \mathrm{~B}$ ). The used soil has $5 \mathrm{~cm}$ depth. The median diameter of soil $d_{50}$ is $0.88 \mathrm{~mm}$. The water depths at the flume end are altered in the following range $(3.7$ to $6.5 \mathrm{~cm})$. The velocity downstream the bridge ranges within 6.6 to $11.6 \mathrm{~m} / \mathrm{sec}$. The time for each test was set as 60 minute. It equals the double values proposed by Negm et al. (2009).

The study clarifies the effect of existing extra-piles on scour at a rectangular pier. The piles are of following characteristics (diameter and spacing= $\mathrm{a} / 2$ ). Five relative extensions 
of new piles are tested $\left(\mathrm{L}_{\mathrm{r}}=1.312,2.187,3.062,3.937\right.$ and 4.812) (see figure 1A). Also, the study clarifies the effect of new abutment upstream old abutments on scour at rectangular pier. Three relative breadths of new abutment of $\mathrm{w}_{\mathrm{r}}=0.5,1.031$ and 1.25are tested (see figure 1B). The lengths of new abutments are the same as the old ones.

\section{The results and comparisons}

\subsection{Comparison with available scour equations}

Figure (3A) shows relationships between related depths of scour $\mathrm{s}_{\mathrm{cr}}$ and $\mathrm{F}_{\text {down }}$ for the base case and Froechlich \& Chitale equations. It can be seen that, the measures are acceptable. Figure (3B) shows the relationship between the developed and the measured depths of scour in $\mathrm{cm}$ unites. The measures are scattered near the perfect line for Froechlich and Chitale equations with $\mathrm{RSQ}=75.9 \%$ and $72.4 \%$, respectively.
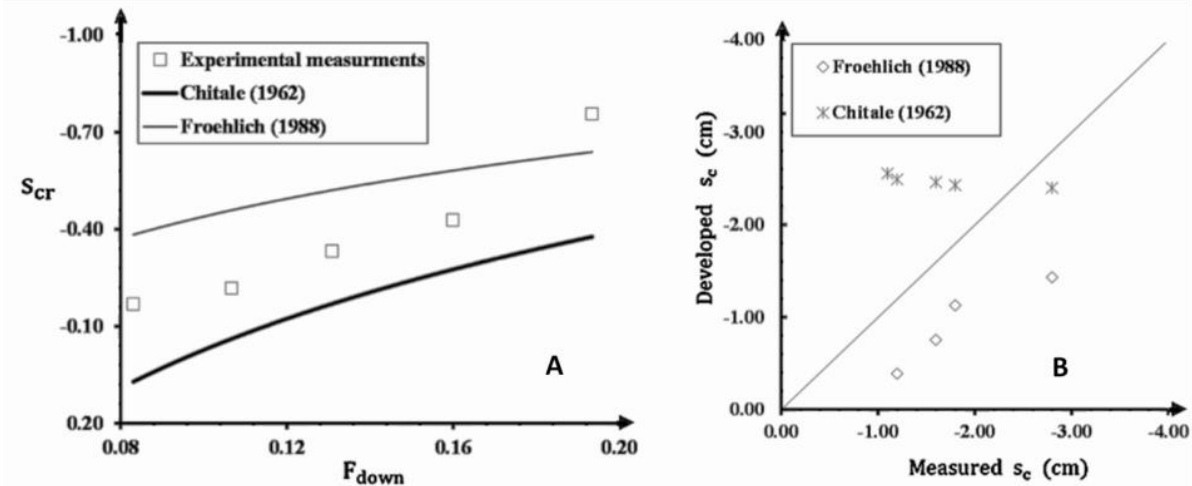

Fig: 3. [A] Relationships between $\mathrm{s}_{\mathrm{cr}}$ and $\mathrm{F}_{\text {down }}[\mathrm{B}]$ Relationships between developed and measured $\mathrm{s}_{\mathrm{c}}$

\subsection{The effect of extra-piles upstream abutments}

Figure (4A) shows relationships between $\mathrm{s}_{\mathrm{cr}}$ and $\mathrm{F}_{\mathrm{down}}$ for different relative extensions of piles (i.e., $\mathrm{L}_{\mathrm{r}}=1.312,2.187,3.062,3.937$ and 4.812). It yielded that, $\mathrm{L}_{\mathrm{r}}=4.812$ gives the least $\mathrm{s}_{\mathrm{cr}}$. In contrast, $\mathrm{L}_{\mathrm{r}}=3.937$ gives extreme values of $\mathrm{s}_{\mathrm{cr}}$.Median value of $\mathrm{s}_{\mathrm{cr}}$ upstream bridge increases by about $50 \%$. Figure (4B) displays relationships between $\mathrm{s}_{\mathrm{cr}}$ upstream piers and $\mathrm{L}_{\mathrm{r}}$ for different $\mathrm{F}_{\text {down. }}$. It yielded that, $\mathrm{s}_{\mathrm{cr}}$ growths for $1.312<\mathrm{L}_{\mathrm{r}}<4.812$.

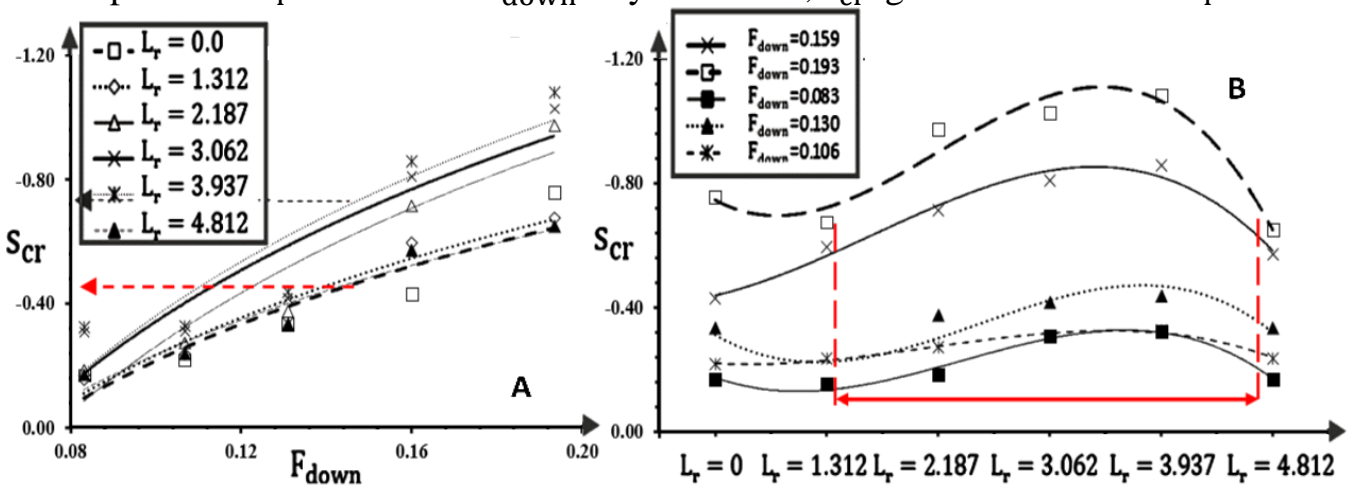

Fig. 4. Results for the first group of measures [A] Relationships between $s_{c r}$ and $F_{\text {down }}[B]$ Relationships $\mathrm{S}_{\mathrm{cr}}$ and $\mathrm{L}_{\mathrm{r}}$ 


\subsection{The effect of extra-abutment upstream abutments}

Figure (5A) shows relationships between $\mathrm{s}_{\mathrm{cr}}$ and $\mathrm{F}_{\text {down }}$ for different relative breadths of additional abutments (i.e., $\mathrm{w}_{\mathrm{r}}=0.5,1.031$ and 1.25). It yielded that, $\mathrm{w}_{\mathrm{r}}=1.25$ gives extreme values of $\mathrm{s}_{\mathrm{cr}}$. It increased the median $\mathrm{s}_{\mathrm{cr}}$ by $95 \%$. In contrast, $\mathrm{w}_{\mathrm{r}}=0.5$ gives the minimum $s_{\mathrm{cr}}$. Figure, (5B) shows relationships between $s_{\mathrm{cr}}$ and $\mathrm{w}_{\mathrm{r}}$ for different $\mathrm{F}_{\text {down }}$. It yielded that $s_{c r}$ increasesas $w_{r}$ increases. The minimum value of $s_{c r}$ is obtained for the case of no additional abutment upstream old bridge (seefigure 5B).

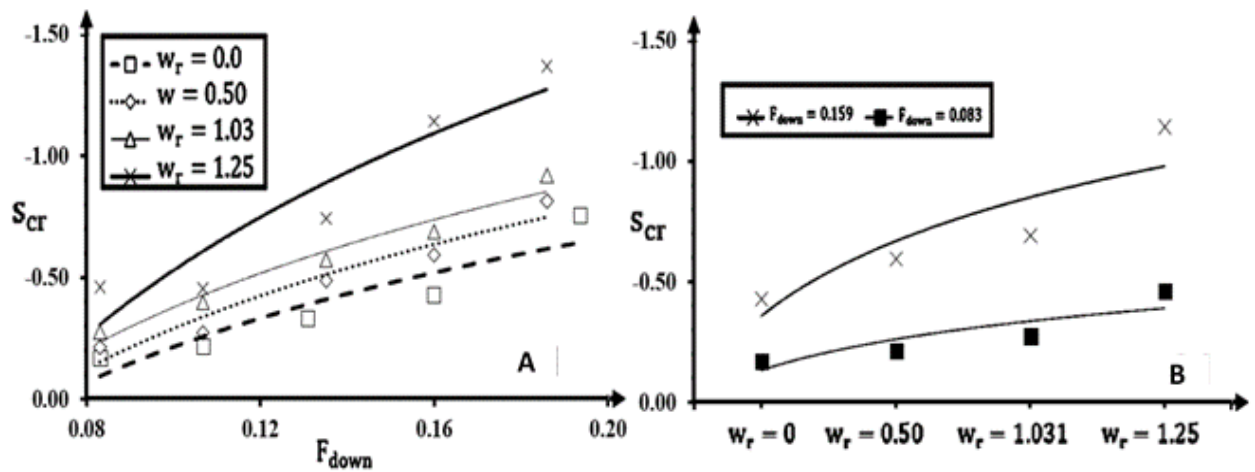

Fig. 5. Results for the second group of measures [A] Relationships between $s_{c r}$ and $F_{\text {down }}$ [B] Relationships between $\mathrm{s}_{\mathrm{cr}}$ and $\mathrm{w}_{\mathrm{r}}$

\subsection{A comparison between optimum results}

Figure (6A) shows relationships between $\mathrm{s}_{\mathrm{cr}}$ and $\mathrm{F}_{\text {down }}$ for the ideal cases of two groups of measures. It yielded that, $\mathrm{L}_{\mathrm{r}}=4.812$ gives the minimums $\mathrm{cr}_{\mathrm{r}}$ compared to the locating of abutments upstream old bridge. In fact, $\mathrm{L}_{\mathrm{r}}=4.812$ keeps scour upstream old bridge constant compared with locating new abutments upstream old bridge (see figure 6B).

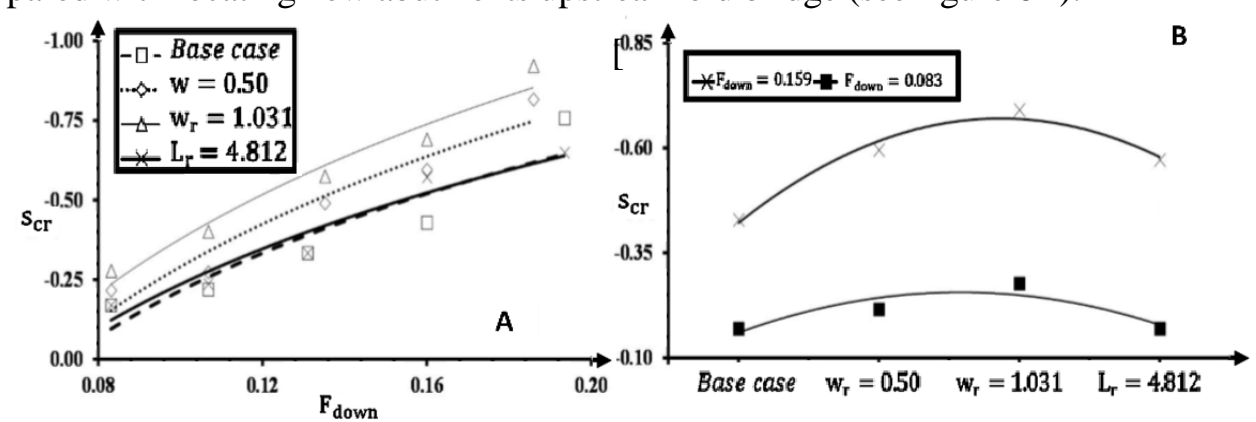

Fig. 6. Results for the two groups of measures [A] Relationships between $s_{c r}$ and $F_{\text {down }}[B]$ Relationships between $\mathrm{s}_{\mathrm{cr}}$ and the optimal cases.

\section{Statistical formulations}

Equations (3\&4)are developed by the employment of theoretical Eq. (2) for the two groups of experimental measures. $80 \%$ of data is applied to create these equations and the rest is used for validation. RSQ of equations (3\&4) are $89.6 \%$ and $91.6 \%$, respectively. It indicates the capability of equations to fit collected points perfectly. Figures (7A and 8A) display relationships between the predicted and the measured $s_{\mathrm{cr}}$ by equations $(3 \& 4)$, respectively. It yielded that, there is a reasonable agreement between the predicted and the measured $\mathrm{s}_{\mathrm{cr}}$. Figures $(7 \mathrm{~B}$ and $8 \mathrm{~B})$ display relationships between the errors and the 
predicted $s_{\mathrm{cr}}$ using Eqs. (3\&4), respectively. There is no apparent trend of errors. Table (1) presents the measured parameters of Eqs. (3\&4).

$$
\mathrm{s}_{\mathrm{cr}}=-40.15+43.77 \ln \mathrm{V}_{\mathrm{r}}+0.003 \mathrm{~L}_{\mathrm{r}}^{3}-6.58 \mathrm{~V}_{\mathrm{r}}-2.93 y_{\mathrm{r}}-0.09 \mathrm{~L}_{\mathrm{r}}+49.85 \mathrm{~F}_{\mathrm{down}}
$$

$$
\mathrm{s}_{\mathrm{cr}}=8758.47-526.03 \ln _{\mathrm{r}}-0.228 \mathrm{w}_{\mathrm{r}}{ }^{3}-8999.78 \mathrm{~F}_{\mathrm{down}}{ }^{0.05}+3.77 \mathrm{~V}_{\mathrm{r}}+
$$

$75.17 y_{r}+0.06 \mathrm{w}_{\mathrm{r}}+61.67 \mathrm{~F}_{\mathrm{down}}$

Table. 1.

Statistical measures of equations $(3 \& 4)$

\begin{tabular}{|l|c|c|c|c|}
\hline \multirow{2}{*}{} & \multicolumn{2}{|c|}{ Equation (3) } & \multicolumn{2}{c|}{ Equation (4) } \\
\cline { 2 - 5 } & Training & Validation & Training & Validation \\
\hline RSQ & $94.0 \%$ & $89.6 \%$ & $93.5 \%$ & $91.6 \%$ \\
\hline Correlation & $96.9 \%$ & $94.6 \%$ & $96.7 \%$ & $95.7 \%$ \\
\hline RMSE & $7.07 \%$ & $12.4 \%$ & $8.1 \%$ & $10.4 \%$ \\
\hline
\end{tabular}
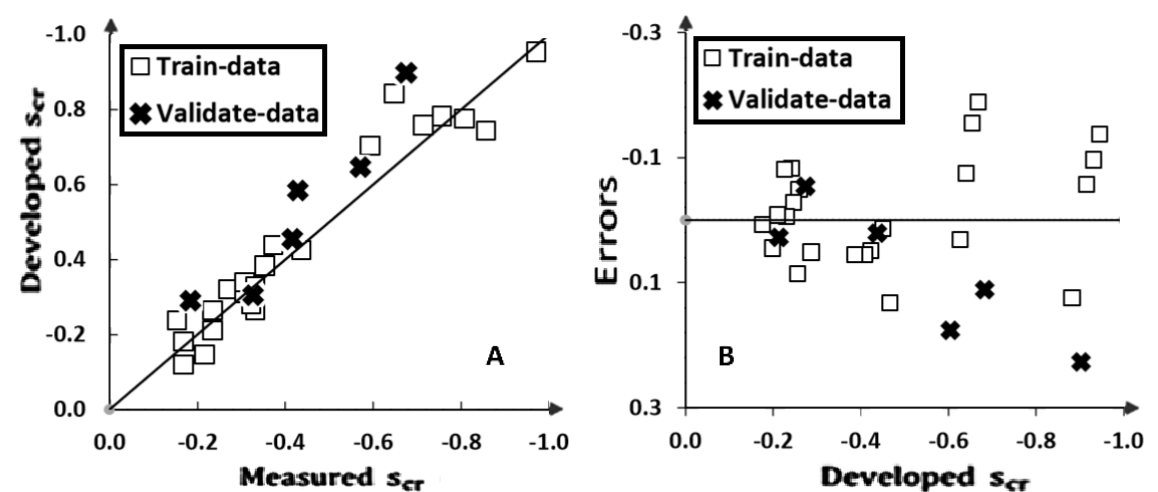

Fig. 7. [A] Relationships between the developeds ${ }_{\mathrm{cr}}$ using Eq. (3) \& the measured ones [B] Relationships between the errors of Eq (3) \& the developeds $\mathrm{cr}_{\mathrm{cr}}$.
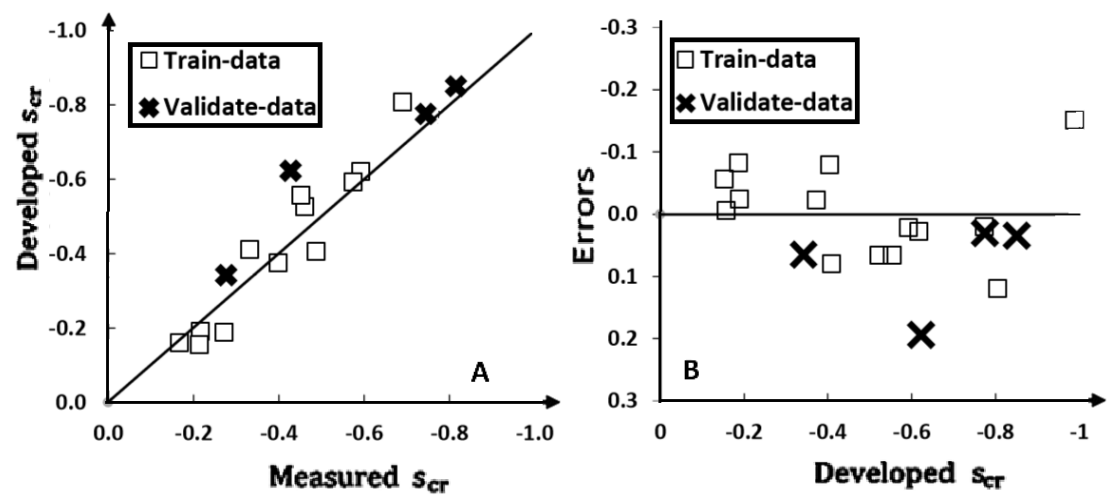

Fig. 8. [A] Relationships between developeds ${ }_{\mathrm{cr}}$ using Eq. (4) and the measured ones [B] Relationships between the errors of Eq (4) and the developeds $\mathrm{cr}_{\mathrm{cr}}$.

\section{Numerical application}

SToRM (System for Transport and River Modeling) in iRIC software [6, 8] is applied to simulate the velocity in the tested model. It is software for the simulation of flow field and it was applied in open channels [6]. SToRM solver is a 2D numerical model in the plan. It simulates the free surface water flow. The major equations are given by Francisco Simões, (2013). 


\subsection{Schematization and the major conditions}

The mesh is divided into irregular cells (see Fig. 9a). The total length and breadth of a domain are $2 \mathrm{~m}$ and $0.4 \mathrm{~m}$, respectively. The cell's extreme area is defined as $0.001 \mathrm{~m}^{2}$.The location of abutments, the rectangular pier and the piles were defined using the hole region option for inspected cases (i.e., $\mathrm{L}_{\mathrm{r}}=0,1.312,3.062$ and 4.812) (seefigures9a, 9b, 9c, and $9 \mathrm{~d})$. The corners of hole regions are defined by coordinates of experiments.

The inflow and outflow conditions are defined as follows: the inflow discharge $=0.00172 \mathrm{~m}^{3} / \mathrm{sec}$ and the outflow stage $=0.038 \mathrm{~m}$. Manning condition is adopted for the calculations.

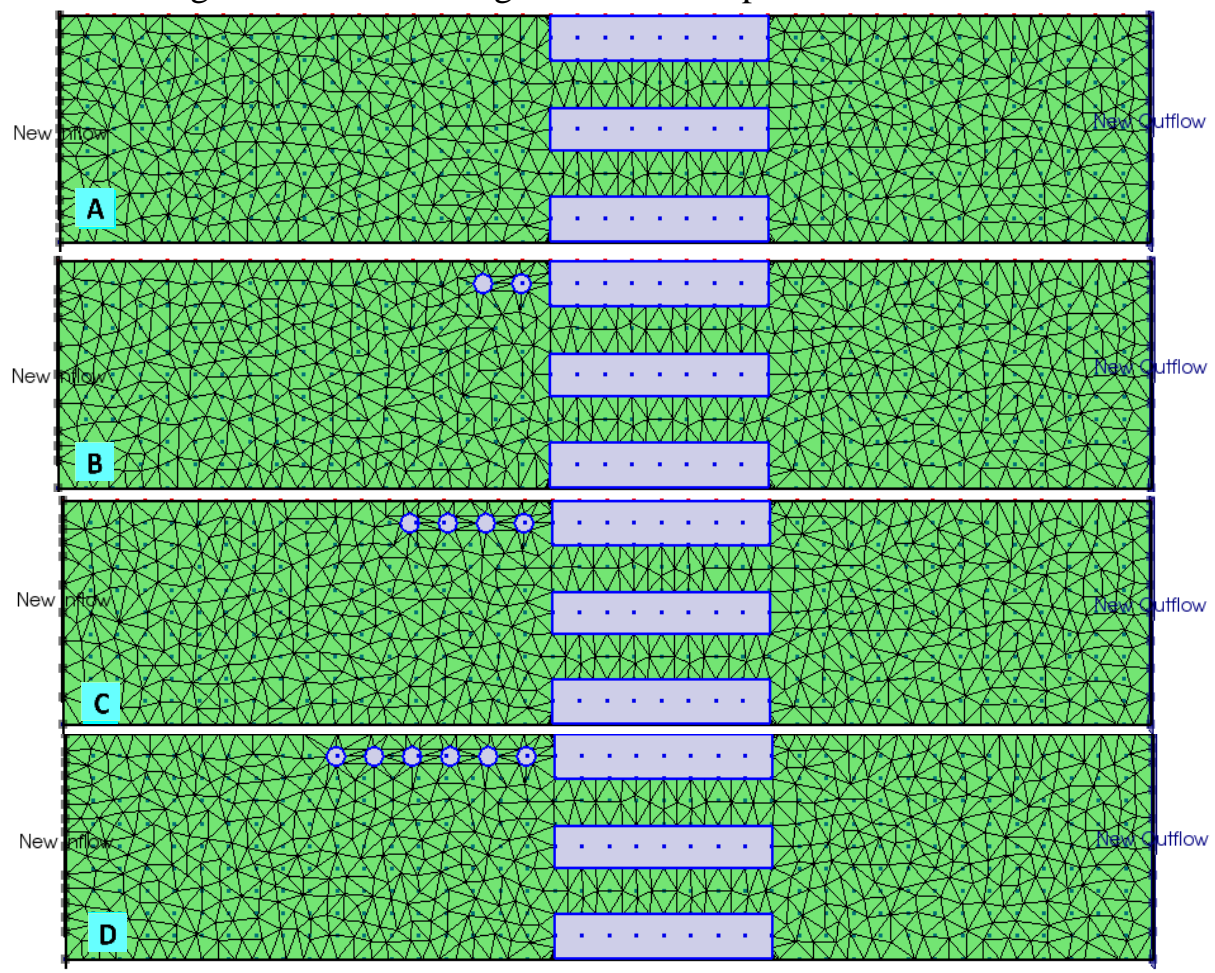

Fig. 9.The mesh of inspected cases $[A]$ Base case $\left(\mathrm{L}_{\mathrm{r}}=0\right)[\mathrm{B}] \mathrm{L}_{\mathrm{r}}=1.312[\mathrm{C}] \mathrm{L}_{\mathrm{r}}=3.062[\mathrm{D}] \mathrm{L}_{\mathrm{r}}=4.812$

\subsection{Numerical results}

The major objective is to investigate the effect of locating extra-piles on the flow field near the rectangular pier. Four cases are numerically modeled. It included that, the base case (i.e., on extra piles), and three cases of different relative extensions of new piles (i. e., $\mathrm{L}_{\mathrm{r}}=1.312,3.062$ and 4.812 ). The tested circular piles are of diameter $\cong \mathrm{a} / 2$.

Figure (10) shows contour maps of velocity magnitude for inspected cases. It yielded that, the area of high velocity is obviously increased near the rectangular pier for $\mathrm{L}_{\mathrm{r}}=$ 3.062 (see figure 10C). It becomes more than the critical flow velocity of median diameter of soil $\left(\mathrm{V}_{\mathrm{c}}=0.355 \mathrm{~m} / \mathrm{sec}\right.$.). It may cause scour increasing near the bridge pier. For $\mathrm{L}_{\mathrm{r}}=$ 1.12 , it can be seen that, the zones of high velocity are generated upstream abutment of bridges (see figure 10B). For $\mathrm{L}_{\mathrm{r}}=4.812$, the velocity near pier's corners and abutments are very small in comparison with others(see figure 10D). 


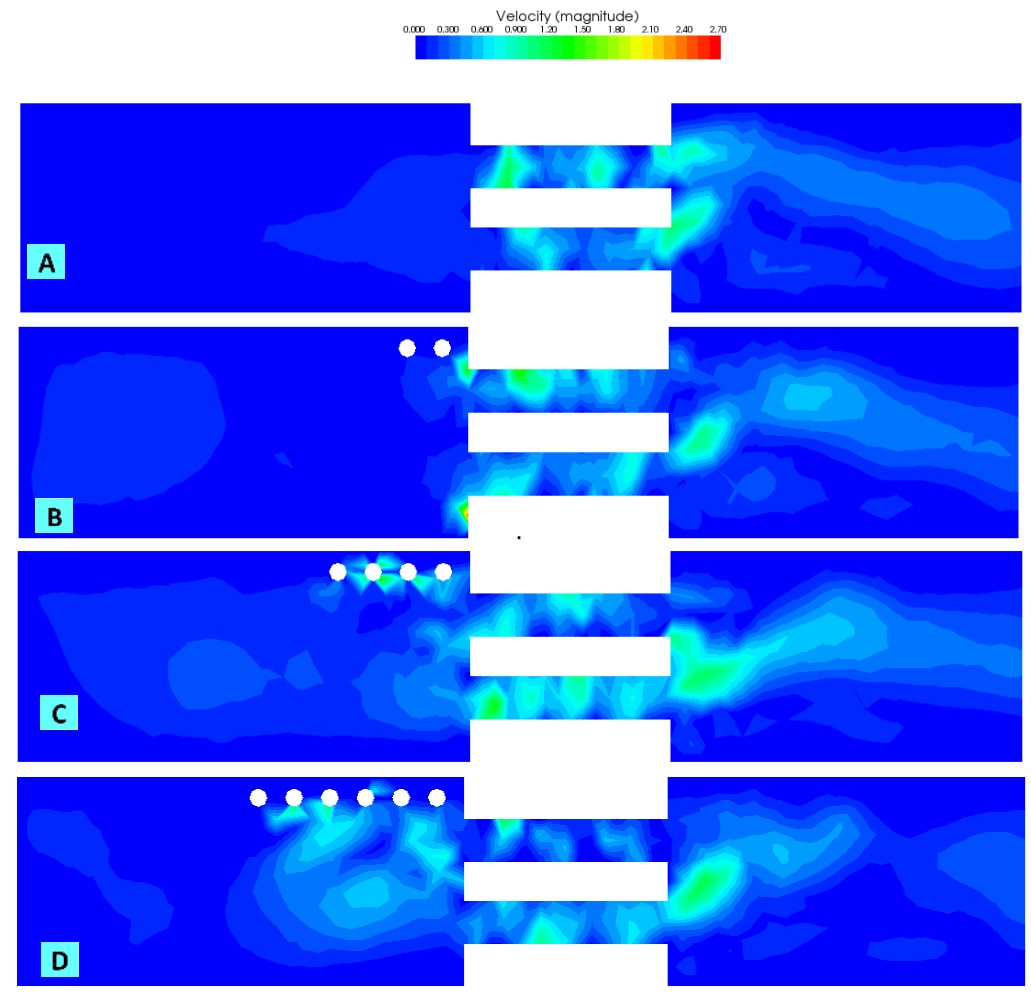

Fig. 10. The maps of velocity magnitude of inspected cases $[A]$ base case $[B] L_{r}=1.312[C]$ $\mathrm{L}_{\mathrm{r}}=3.062[\mathrm{D}] \mathrm{L}_{\mathrm{r}}=4.812$

Figure (11) shows the velocities victors for different inspected cases. The velocity near the rectangular pier for $L_{r}=4.812$ is lower than the other cases (see figure 11D). In contrast, the velocities victors of $\mathrm{L}_{\mathrm{r}}=1.312$ are very long at the upstream corners of the abutments (see figure 11B). In addition, velocity victors of $L_{r}=3.062$ are very long at the upstream corners of piers.

When $L_{r}=1.312$, a small wake zone is formed beside the piles (see figure 11B). It transformed a part of flow directly to the abutment in the other side. As a result, the velocity's victors are very long at the upstream corners of the abutments. It may affect the scour process at the abutment.

When $L_{r}=3.062$, a small turbulence zone is formed beside the piles and a small wake zone is formed upstream piers (see figure 11C). It directed a part of flow to pass out of the other vent of the bridge. As a result, the velocity's victors are very long near the pier and at the upstream corner of the abutment. There is a weak zone upstream bridge of $\mathrm{L}_{\mathrm{r}}=4.812$. This zone acts as a block against the major flow lines. The noticeable result is reducing the flow velocity values near the rectangular pier (see figure 11D). 


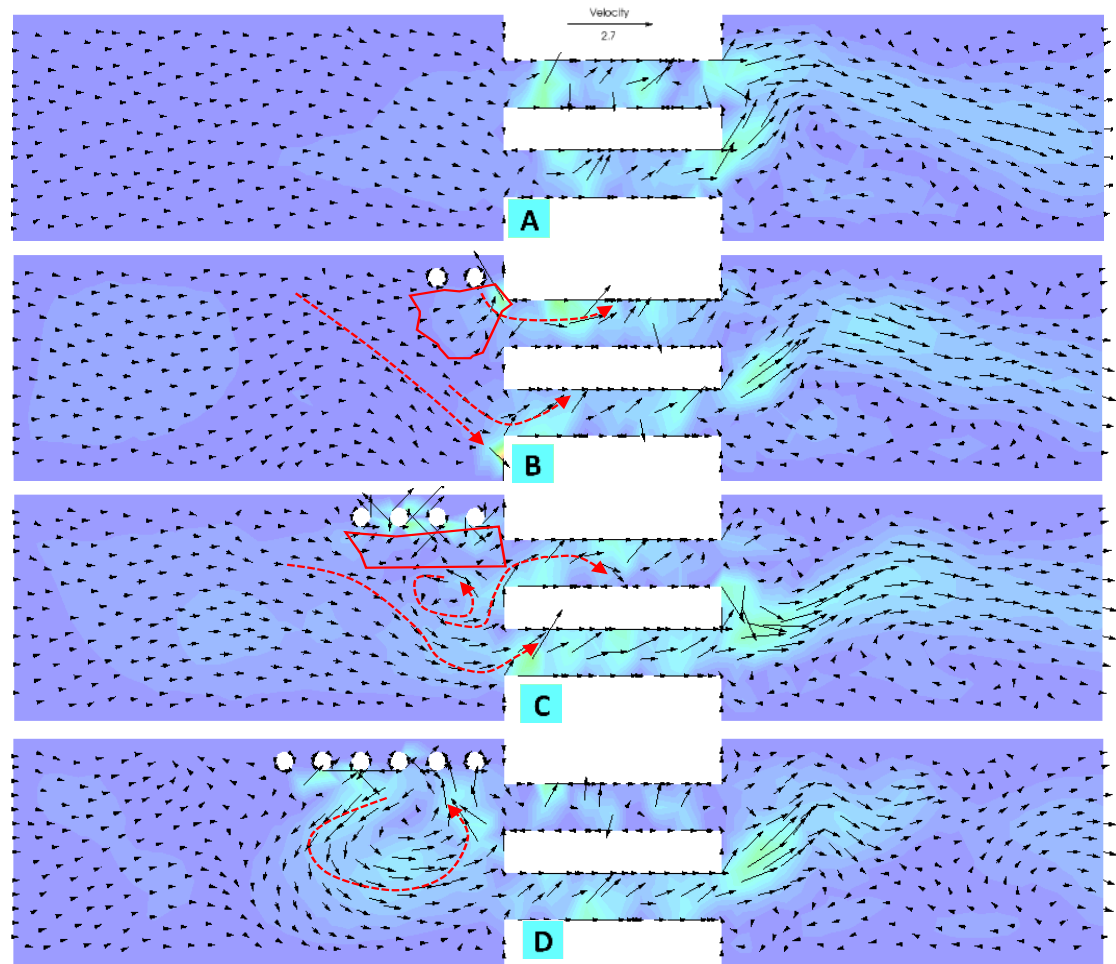

Fig. 11.The horizontal flow velocity victors $[A]$ base case $[B] L_{r}=1.312[C] L_{r}=3.062[D] L_{r}=4.812$

\section{The conclusions}

The modeling of scouring and flow velocities at rectangular piers at the presence of extra-supports is offered in this research with the following conclusions:

1. The additional piles of $\mathrm{L}_{\mathrm{r}}=4.812$ produces the minimal $\mathrm{s}_{\mathrm{cr}}$ upstream bridge. In contrast, $\mathrm{L}_{\mathrm{r}}=3.937$ gives extreme values ofs $\mathrm{c}_{\mathrm{cr}}$. Median value of $\mathrm{s}_{\mathrm{cr}}$ upstream bridge increased by about $50 \%$ in comparison with the base case. $\mathrm{s}_{\mathrm{cr}}$ upstream rectangular pier increased for $1.312<\mathrm{L}_{\mathrm{r}}<4.812$.

2. The additional abutment of $\mathrm{w}_{\mathrm{r}}=1.25$ gives extreme values ofs cr $_{\text {upstream }}$ rectangular pier. It increased median $\mathrm{s}_{\mathrm{cr}}$ by $95 \%$,

3. Simple predicting equations for $\mathrm{s}_{\mathrm{cr}}$ were developed. RSQ of developed equations are $89.6 \%$ and $91.6 \% \%$, respectively.

4. The results using SToRM solver in iRIC yielded that, the piles of $\mathrm{L}_{r}=$ 4.812produces the minimal flow velocity at rectangular piers. The area of the high velocity was increased for $L_{r}=3.062$, while it was at the minimal value near the abutments and pier for $\mathrm{L}_{\mathrm{r}}=4.812$.

\section{REFERENCES}

[1]Deng, L. and Cai, C. (2010), "Bridge Scour: Prediction, Modeling, Monitoring, and Countermeasures-Review”, Pract. Period. Struct. Des. Constr., Vol.15, No.2, pp. 125-134.

[2]Elfiky, M. M., Negm, A. M., Owais, T. M.,\&Nassar, M. (2002),“A 2-D Model Simulating Sediment Transport In Shallow-Wide Streams (SED-2)”, In Proc. of $5^{\text {th }}$ Int. Conf. on HydroScience and Engineering, pp. 16-21. 
[3]Elfiky, M. M., Negm, A. M., Attia, M. I., \& Nassar, M. H. (2004), "Study of navigation requirements in the Nile River at Elbogdady area uses a 2-D sediment transport model", In Proc. of $2^{\text {nd }}$ Int. Conf. On Fluival Hydraulics June (pp. 23-25).

[4]Elfiky, M. M., Negm, A. M., Owais, T. M., \& Nassar, M. A. (2010), "Computational models for analyzing scouring problems at Nile River", In Proceedings of the $9^{\text {th }}$ Int. Conf. on Hydrodynamics, pp. 11-15.

[5]Esmaeili, T., Dehghani, A. A., Zahiri, A. R., \& Suzuki, K. (2009). 3D numerical simulation of scouring around bridge piers (case study: Bridge 524 crosses the Tanana River). World Academy of Science, Engineering and Technology, 58, 1028-1032.

[6] Francisco J.M. Simões, (2013), "Using SToRM-A Short Primer", http://iric.org/en/software/?c=8.

[7]Gogus, M. and Dogan, A. (2010), "Effects of Collars on Scour Reduction at Bridge Abutments", Scour and Erosion, pp. 997-1007.

[8] iRIC Software, iRIC version2.3 (32bit), http://i-ric.org/en/downloads.

[9]Li, H., Barkdoll, B., Kuhnle, R., and Alonso, C. (2006), "Parallel Walls as an Abutment Scour Countermeasure", J. Hydraul. Eng., Vol.132, No.5. pp. 510-520.

[10] Melville, B. (2008), "The Physics of Local Scour at Bridge Piers", 4thInt.Conf. on Scour and Erosion, pp. 28-40.

[11] Mohammed T.A., M. J. M.M. N., A. Ghazali, B. Yusuf and K. Saed, (2007), "Physical Modeling of Local Scouring around Bridge Piers in Erodable Bed”, J. King Saud Univ., Vol. 19, Eng. Sci. (2), pp. 195-207.

[12] Mohamed, Y. A., Nasr-Allah, T. H., Abdel-Aal, G. M., \&Awad, A. S. (2015). Investigating the effect of curved shape of bridge abutment provided with collar on local scour, experimentally and numerically. Ain Shams Engineering Journal, 6(2), 403-411.

[13] Mojtaba S., Navid A. V. and Mehdi A. M., (2012), "Buried Wing Versus Wing Wall as Abutments and Spur Dykes Scour Countermeasure", Asian Journal of Applied Sciences, Vol. 5, No. 4, pp. 192-204.

[14] Mowafy M. H. and Fahmy M. R., (2001), "The Effect of Constructing Two Adjacent Bridges on the Flow Characteristics and Local Scour around Bridge Piers", 6 ${ }^{\text {th }}$ Int. Water Technology Conf., IWTC 2001, Alexandria, Egypt.

[15] Mowafy, M. H., \& EI-Sayed, A. H. (2000), "Effect of weeds accumulation on scour depth around bridge piers", Eng. Res. J., Helwan Univ., Fac. of Eng., Cairo, Vol. 70, pp. 83-94.

[16] Nassar, M. A. (2011), "Multi-parametric sensitivity analysis of CCHE2D for channel flow simulations in Nile River", Journal of hydro-environment research, Vol. 5, No. 3, pp.187-195.

[17] Negm A.M., Gamal M. M., Abdalla Y. M. and Fathy A.A. (2009), "Control of local scour around bridge piers using current deflector", $13^{\text {th }}$ Int. Water Technology Conf., IWTC 13 2009, Hurghada, Egypt, pp 1711-1722.

[18] Negm, A. M., Abdulaziz, T., Nassar, M., \&Fathy, I. (2010). Predication of Life Time Span of High Aswan Dam Reservoir Using CCHE2D Simulation Model. In Proceeding $14^{\text {th }}$ Int. Water Technology Conf., (pp. 611-626).

[19] Oben-Nyarko, K. and Ettema, R. (2011), "Pier and Abutment Scour Interaction", J. Hydraul. Eng., Vol.137, No. 12, pp.1598-1605.

[20] Radice, A. and Davari, V. (2014), "Roughening Elements as Abutment Scour Countermeasures", J. Hydraul. Eng., Vol.140, No. 8.

[21] Sheppard D. Max, HuseyinDemir and Bruce Melville, (2011), "Scour at Wide Piers and Long Skewed Piers”, NCHRP REPORT 682, National Academy of Sciences, ISBN 978-0-309-15537-3. 


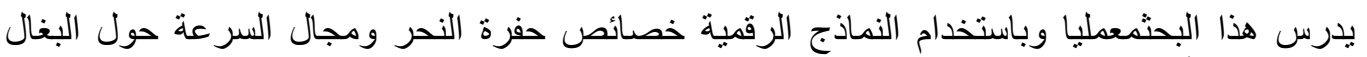

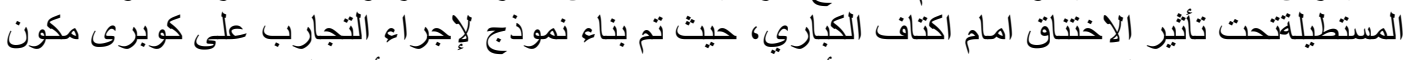

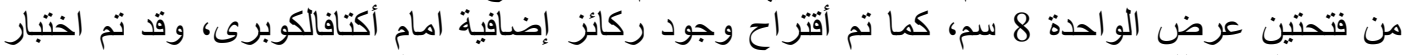

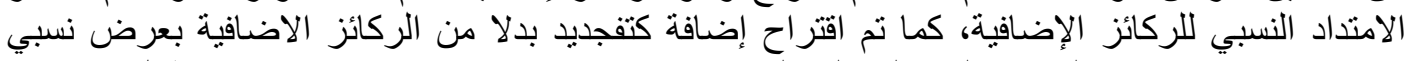

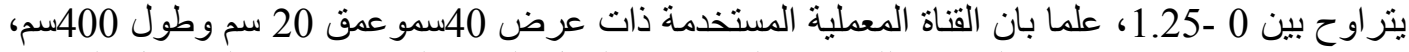

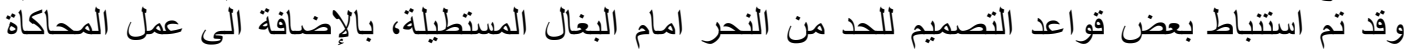

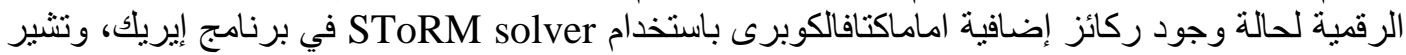

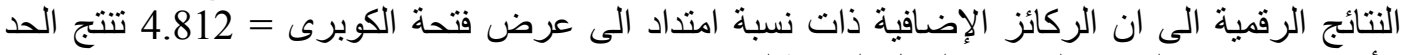
الأدنى من سر عة التدفق بالقرب منالبغال المستطيلة. 